Magdalena Wasąg

Uniwersytet Łódzki*

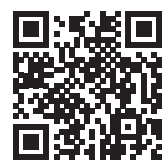

\title{
Epistolography as a Challenge
}

\begin{abstract}
The article briefly confronts different research perspectives on epistolography. The fundamental Teoria listu (Theory of a Letter) by Stefania Skwarczyńska is indicated as an important reference for many concepts. The category of a beautiful letter proposed by Skwarczyńska is presented by the example of the correspondence between Wisława Szymborska and Kornel Filipowicz - Listy. Najlepiej w życiu ma twój kot (Letters. Your Cat Has the Best in Life). The letters of the future Nobel Prize winner and the master of the storyteller harmoniously combine life and literary elements. They are characterised by irony and humour, which are specific codes of communication. Their form and concepts are evidence of the correspondents' passionate and strong relationship. The sensitivity to nature shown in them was presented in the context of empathetic imagination. It was linked to both Filipowicz's biographical experiences and his creative practices, threads that help in the origin of texts such as the short story Krajobraz doskonaty (Perfect Landscape) from the volume Śmierć mojego antagonisty (Death of My Antagonist).

Nowadays, the need for interdisciplinarity has been pointed out as one of the most important postulates concerning the study of epistolography. The bilateral nature of biography and correspondence continues to be an inspiring issue. The communication paradox of the letter, which is both a dialogue and a monologue, also returns in the investigations of researchers. In the context of the aforementioned studies, the letter continues to fascinate as a phenomenon on the borderline of life and art. For some artists, the letter had a community-creating power. This very meaning was especially emphasised in the perspective of searching for spiritual community, tightening important bonds, lasting and deep friendships based on certain rules. Volumes of correspondence of writers-friends, among others, Julian Tuwim, were cited as an example. The article is an invitation to develop and expand the study of both published correspondence, as well as letters resting in archives in Poland and abroad.
\end{abstract}


* Uniwersytet Łódzki, Wydzial Filologiczny, Zakład Literatury Polskiej XX i XXI w. ul. Pomorska 171/173,90-236 Łódź

e-mail: magdalena.wasag@uni.lodz.pl 
$[\ldots]$ the beauty of the letter demands that it be effective on the line of its important aim, that its weight of genre should affect the life relations from which it grew, for which it was intended, with which it is intertwined, so that it can be sensed that it is not really something literally detached from life, but it is part of it.

(Skwarczyńska 2006: 333-334) ${ }^{1}$

On November 12, 1968, Wisława Szymborska was writing from Zakopane to Kornel Filipowicz:

\section{Dear Kornel!}

Today is Tuesday, the day that brings you dramatic experiences. But well, without knowing the hospital, you can't be a fully modern man. This is not my theory, but Col. Maciąg's, who claims that a man of the 20th century should have had three experiences behind him: 1) prison, 2) divorce, 3) hospital, and only then he gains the so-called full awareness [...]. (Szymborska, Filipowicz 2016: 148)

In the letters of the future Nobel Prize winner and the master of storytelling, literary and life elements are harmoniously manifested. They are characterized by irony and humor, which become a specific communication code. If we were looking for a key moment that influenced the increased dynamics of Szymborska and Filipowicz's correspondence, we could clearly indicate the nearly six-month treatment of the poet in the Zakopane sanatorium. However, experiencing the disease, forced isolation and the loneliness associated with it were overcome by the correspondents' creative invention, their imagination and absurd joke. If we tried to follow the invariably current path proposed by Stefania Skwarczyńska and consider what the beauty of these letters is, we will redefine the question about their essence. We will touch upon decisive issues, such as the remarkable personality of the correspondents who, despite the bleak reality of the People's Republic of Poland, everyday problems with food supply, struggles with bureaucracy and censorship, write to each other

\footnotetext{
1 All quotations translated from Polish.
} 
passionately and create their intimate world. The interpenetration of life and fiction, a love game, playing roles of Countess Heloiza Lanckorońska and Eustachy Pobóg-Tulczyński are special indicators of these letters.

It is worth to mention that in correspondence, like in an exceptional laboratory, the readers discover the sensitivity of Szymborska and Filipowicz to all forms of existence, plants and animals. "Your cat has the best in life" is a phrase that illustrates the relationship of correspondents with empathetic imagination. Letters, whose main characters are nature, cats, dogs, and birds, open intriguing interpretations. They allow you to penetrate the creative workshop of writers. In the case of Filipowicz, whose stories are nuanced by, among others humananimal relationships, the observations he made at campsites and summarized by Szymborska acquire an important meaning both in terms of the genetics of his texts and biographical threads. On July 4, 1971 Filipowicz wrote: “[...] we are already camping under 3 oaks, $15 \mathrm{~km}$ from Śrem, 12 hours of shade, $30 \mathrm{~m}$ to [unread], $50 \mathrm{~m}$ to the reservoir. Mosquitoes - there aren't any. The landscape is so beautiful, one could say - too beautiful, as if it would be destroyed in a moment" (Szymborska, Filipowicz 2016: 245). The humorous tone of information about the camp was overcome by a surprisingly disturbing sentence. It seems that here Filipowicz can be known as a man of the $20^{\text {th }}$ century who is not deceived by the carefree charm of the beautiful landscape. As a concentration camp prisoner, he found out how the destruction machine works. It can be assumed that he used the traumatic experience of war confronted with the perfection of the landscape, which can be found in the letter to Szymborska, as the inspiration for writing the short-story Krajobraz doskonaty (Perfect Landscape) ${ }^{2}$ published in 1972 in Volume Śmierć mojego antagonisty (Death of My Antagonist). Filipowicz described the feeling of danger with insight, even in a perfect environment. Even in an extremely perfect environment, Filipowicz described the feeling of danger with insight. This is an even more valuable and poignant observation when we place it in biographical, historical and political contexts. One can see in it a more general characteristic of the condition of contemporary man, who experienced the devastation of war and became convinced of the transience of all beauty.

In the $21^{\text {st }}$ century, when the epistolography related to the traditional paper form of writing disappears (see Adamczewska 2012: 531-533), the correspondence of Szymborska and Filipowicz becomes a priceless testimony to old practices, carefully selected writing paper, supplements in the form of leaves, notes, collages, postcards and drawings. It also remains a proof of the sensual dimension of correspondence - a phenomenon bordering on life and art.

\section{On the borderlands}

Continuously appearing new volumes of correspondence prove the interest of readers in the letters, their author, form, style, historical background, etc. The proposed arrangement according to addressees or subject matter influences the reader's perception, illuminates the author in a network of various relationships, highlights specific issues. Collections of pub-

2 "Let me just add that there was something very disturbing about the beauty of this place. Something that made us feel somehow unsure of our fate after a few days of staying here, as if we were endangered by something. Where was it coming from? Perhaps it is from this complete perfection of the landscape that surrounds us? [...] Or maybe the landscape was not to blame for anything, maybe the source of anxiety was in ourselves?" (Filipowicz 2021: 162) 
lished letters from the $20^{\text {th }}$ century have been dominated by the correspondence of writers (see Czermińska 1993). Examples of outstanding epistolographers can be multiplied, it suffices to mention Bruno Schulz, Stanisław Witkiewicz, Stanisław Ignacy Witkiewicz, Jarosław Iwaszkiewicz, Julian Tuwim, Jerzy Giedroyc, Jerzy Stempowski, Czesław Miłosz, Sławomir Mrożek and Stanisław Lem. It should be stressed, however, that letters are studied not only by literary scholars, but also linguists, historians, sociologists, anthropologists and cultural scientists.

Today, the need for interdisciplinarity is still undoubtedly one of the most important postulates concerning the study of epistolography. The analysis of letters with the use of various research methods seems to be a solution, which is connected with specific consequences described by researchers studying, among others, relations between epistolography and biography. Tools developed in the study of autobiography are often used to describe correspondence. ${ }^{3}$ Małgorzata Czermińska in her monograph devoted to autobiographical attitudes distinguishing the literature of personal document in the introduction to the relation of the letter and literary works recapitulated the scientific approach to epistolography, which was treated as a historical source, a kind of document ${ }^{4}$ and a commentary on creativity. ${ }^{5}$ Epistolary forms, due to their specificity, elude strictly literary methods. Skwarczyńska wrote about the necessity of referring, among other things, to biography in applied literature studies in her fundamental Teoria listu (Theory of the Letter):

Since the reality surrounding the letter exceeds the boundaries of literary phenomena, and concerns purely life events, it can only be grasped by historical science, and thus by methods appropriate to this science. In particular, biographical studies will be fundamental, which will allow us to learn about the life of the author and his addressees. (Skwarczyńska 2006: 334)

It comes as no surprise, then, that it is in a monograph devoted to scientific biography that Anita Całek addresses the problem of correspondence. The researcher, following in the footsteps of the already canonical diagnoses of Jan Trzynadlowski (see 1975), has drawn attention to the bilateral character of biography and correspondence. Referring to the areas in which epistolography has been located (autocreative, communicative, anthropological), she tries to point to useful analytical tools for re-constructing the life of an author (Całek 2013: 197). This is due to the fact that the interpenetration of biographical and epistolographic perspectives significantly influences the choice of specific research tools. It is a truism that letters, both published and already critically elaborated, as well as those found in archives, often dispersed, are important source material for a biographer. It seems that Całek sympathizes with the existential perspective in epistolographic studies proposed by Kazimierz Cysewski, according to whom: "What is necessary is to see letters as a comprehensive picture of the heart and fate, a picture that is not only intentional, and therefore to 'include' in the semantics of letters the drawing in them of the picture of the author and the addressee" (1997: 109).

3 Elżbieta Rybicka wrote about the consequences of autobiographical epistolography. See Rybicka 2004: 46-48.

4 Stefania Skwarczyńska wrote about the letter as an "autonomous literary genre" in her 1937 monograph, opposing the attitude of treating the letter exclusively as a subordinate, documentary form.

5 See Czermińska 2000: 252. Elżbieta Rybicka introduced into Polish literary studies the typology of a letter by Brigitte Diaz, who proposed an understanding of a letter taking into account its four co-existing forms: document, text, discourse and action. See Diaz 2002. 
According to Cysewski's recognition, self-creation is a part of the author's picture. ${ }^{6}$ In connection with certain procedures, which are supposed to create the desired picture of the author, a kind of construction is created. Thus, taking into account the perspective of the text, Cysewski introduced the term "epistolary subject," which is not the same as the person of the real author. In this approach it becomes important to discover the epistolary strategy, which determines, among other things, the manner of communication with the addressee and is an expression of the author's personality. In the context of these considerations, an original concept is the New Theory of the Letter [Nowa teoria listu], in which Anita Całek proposes understanding the letter as a cultural text:

[...] as a genre of speech it constitutes a separate, autonomous whole, specifically composed and determining its own internal communicative rules, in parallel it interacts with reality (towhich it refers), the sender (and the publisher and the researcher - as senders of the 'second' and also the 'third' level) and the recipient (and readers - recipients on further levels of published or publicised correspondence). (Całek 2019: 82)

It is also worth mentioning an interesting postulate by Lucyna Marzec who, referring to William J.T. Mitchell's theory of medium, wrote "A letter resembles a medium in many aspects it is 'an embodied emissary, not the message itself', it is a material way of communicating [...]" (Marzec 2015: 94). The communicative paradox of the letter, which is both a dialogue and a monologue, reappears in the investigations of researchers (Skwarczyńska 1975). Moreover, the psychological dimension of correspondence also appears, when the epistolographer tries to penetrate the psyche of the addressee. Thus, psychological and philosophical categories also prove important in the description of letter relations. But not only. An interesting subject is the exchange of letters as a kind of dramatic dialogue. In this context Magdalena Popiel takes Stanisław Wyspiański's letters and identifies the artist's letter as a genre of epistolographic narration. ${ }^{7}$ According to the researcher, the playwright's dialogue and letter writing were guided by certain rules. One of their conditions was continuity. Dialogue and correspondence have their own rhythm, which determines their very essence. The lack of a timely response ruins the work. For Wyspiański, letter-writing means the co-creation of "a conscious community of aims, rules and values" (Popiel 2004: 119). It seems that the aforementioned community makes clear the importance of epistolography in the creative practices of artists, for whom letters were a special medium of interpersonal bonds - they had a community-forming power (see Ziołowicz 2014). Community, i.e., among other things,

6 According to Cysewski:

The sentences that we consider as expressions of self-creation practices can be both true and false. It follows that self-creation is not a problem of truth or falsity, but of the type and 'direction' of the meanings of a text, it is a certain way of using language, it is one of the functions of language in a piece. (Cysewski 1997: 104).

7 "To whom does the artist write? To the artist, of course. [...] The discourse of the letter will focus on the confirmation of the artist's identity. In epistolary communication, the dialogue with a specific addressee, a situation fundamentally different from a journal, diary or autobiography, is a specific provocation for the artist's creative identity. Two elements with artefactual power enter into this Me-You configuration: distance and medium. The distance and the sheet of paper filled with characters create the scenario of the performance. They also create the role into which the sender enters: the role of the artist in activity, the artist in action" (Popiel 2004: 116). 
"something that connects, unites; a bond, cohesion" (Wspólnota). It is implicitly also a spiritual community, which the correspondence of Bruno Schulz, among others, testifies to the search for (Schulz 2008). In other words, these are letters that help tighten important bonds, these are letters that essentially introduce the artist into the family of creative spirits, that become a manifestation of lasting and deep friendship. In this context, we can recall the excellent correspondence of Julian Tuwim to his writer-friends. The choice of title is obviously not accidental. ${ }^{8}$ It is significant that a specific key of "friends-writers" or more generally "friends-artists" was also used by other publishers when preparing volumes of correspondence for publication. ${ }^{9}$ (An interesting context for the correspondence of writers-friends are also letters, in which the authors informed about breaking the friendship, so-called divorce letters sent by Lem).

In his Introduction to Tuwim's letters, Tadeusz Januszewski explained, among other things, the difficulties and complexities of their editing, and pointed out the gaps, the filling of which remains in the realm of conjecture. Difficulties were supposed to be caused, for example, by the establishment of the place where the letter was written. On a number of occasions, it turned out that the lack of indications in the text and the scant supply of information made it impossible to establish it precisely. Reading letters very often resembles the practice of deciphering meanings. In private correspondence, which was not intended for third parties, the sender of the letter (the epistolographer) clearly addresses only the addressee of the letter. Moreover, the references and allusions written in it are completely enigmatic for the uninitiated recipient (the reader who is not the addressee). ${ }^{10}$ Czermińska's observation concerning the separation of the roles of the addressee and the reader of the correspondence is appropriate for this communicative situation. ${ }^{11}$

8 Tadeusz Januszewski explained in the Introduction to Tuwim's letters:

The publisher particularly wishes to emphasise that he does not feel competent to give an opinion on a matter as delicate as friendship, and it was not his intention to divide the addressees into 'friends' and 'others'. If, despite this, the book is entitled Letters to friends-writers rather than Letters to writers, it is because the direction of penetration has become clearer. In particular, the volume endeavours to include, as far as was possible today, letters to his old and well-known friends. [...] This volume shows primarily Tuwim's relationships with other writers. That is why the letters were left in separate groups, which will allow better tracing of the development of friendly contacts. Therefore, each group was preceded by an introductory note presenting the "history of friendship" in a very brief manner, and especially information and materials which were not included in the footnotes. This arrangement - modelled, by the way, on the excellent edition of Staff's letters - results from the content of the book and cannot be repeated in all the volumes. (Januszewski 1979: 5-6)

9 See, among others, Julia Hartwig W kregu przyjaźni (In circle of Frendship) (2012).

10 An important distinction between the terms "addressee" and "recipient" in the case of epistolography was also stressed by K. Cysewski:

I assume that an addressee is a person to whom the letter was written, a concrete, semantically designated reader; the recipient, on the other hand, is the "peeper" of someone else's correspondence, a reader who is not the addressee. (Cysewski 1997: 106)

Czermińska notes that:

A complete separation between addressee and reader only exists in the case of correspondence that is clearly not intended for third party use. Then the "You" is directed exclusively to the addressee, the reader does not find there any place intended for himself, and sometimes this leads to a complete misunderstanding of the text: only the publisher's footnote opens before the uninitiated reader some allusion or a kind of "private cipher" in the form of an abbreviation, nickname, etc. (Czermińska 2000: 263) 
The theories and methodological proposals briefly outlined in this article obviously do not exhaust the multitude of perspectives in epistolographic research. They merely announce various possibilities and approaches. In 2018, "Zagadnienia Rodzajów Literackich" ("The Problems of Literary Genres") published an article by Jakub Osiński, ${ }^{12}$ who carried out a reconnaissance on emigration epistolography (1945-1989) and postulated the necessity of research on emigration correspondence of a different nature than domestic correspondence. It is worth to repeat this appeal at the moment of publication of this volume dedicated to the subject of epistolography and the challenges facing researchers of both published correspondence and letters kept in archives in Poland and abroad. I hope that the texts gathered in this volume are a proof of the need to develop and extend research on epistolography, as they take into account very different theoretical perspectives and interpretative ideas. They are also testimony to a particular continuity, creative references to Teoria listu (Theory of the Letter) by Stefania Skwarczyńska.

I cordially invite you to read a special issue devoted to epistolography.

(Translated by Kamil Wasąg)

\section{Bibliography}

Adamczewska Izabella (2012), List [in:] Stownik rodzajów i gatunków literackich. Nowe wydanie, ed. Gazda G., Wydawnictwo Naukowe PWN, Warszawa.

Całek Anita (2013), Biografia naukowa: od koncepcji do narracji. Interdyscyplinarność, teorie, metody badawcze, Wydawnictwo Uniwersytetu Jagiellońskiego, Kraków.

Całek Anita (2019), Nowa teoria listu, Księgarnia Akademicka, Kraków.

Cysewski Kazimierz (1997), Teoretyczne i metodologiczne problemy badań nad epistolografia, "Pamiętnik Literacki", issue 1.

Czermińska Małgorzata (1993), Epistolarne formy [in:] Stownik literatury polskiej XX wieku, ed. Brodzka A. et al., Zakład Narodowy im. Ossolińskich, Wrocław.

Czermińska Małgorzata (2000), Autobiograficzny trójkąt. Świadectwo, wyznanie i wyzwanie, Universitas, Kraków.

12 See Letters by Polish Immigrants after The Second World War (1945-1989). A Research Reconnaissance (Osiński 2018). 
Diaz Brigitte (2002), L’épistolaire ou la pensée nomade. Formes et fonctions de la correspondance dans quelques parcours d'écrivains au XIX siècle, Presses Universitaires de France, Paris.

Filipowicz Kornel (2021), Krajobraz doskonaty [in:] Filipowicz K., Formikarium, czyli w moim świecie mrówek. Opowiadania, select. and introd. Dauksza A., Wydawnictwo Znak, Kraków.

Hartwig Julia (2012), W kręgu przyjaźni [in:] Korespondencja. Artur Międzyrzecki i Julia Hartwig, Czestaw Mitosz, Wydawnictwo Literackie, Kraków.

Januszewski Tadeusz (1979), Introduction [in:] Tuwim J., Listy do przyjaciót-pisarzy, ed. Januszewski T., Czytelnik, Warszawa.

Marzec Lucyna (2015), List, "Forum Poetyki”, no. 1 (summer), http://fp.amu.edu.pl/wp-content/uploads/2015/07/Lucyna_Marzec_List_lato_2015.pdf [access: 20.12.2021].

Osiński Jakub (2018), Letters by Polish Immigrants after The Second World War (1945-1989). A Research Reconnaissance, "The Problems of Literary Genres", issue 3.

Popiel Magdalena (2004), List artysty jako gatunek narracji epistolograficznej. O listach Stanistawa Wyspiańskiego, “Teksty Drugie”, no. 4.

Rybicka Elżbieta (2004), Antropologiczne i komunikacyjne aspekty dyskursu epistolograficznego, “Teksty Drugie”, no. 4.

Schulz Bruno (2008), Księga listów, collected and prepared for printing by Ficowski J., 3rd ed., słowo/obraz terytoria, Gdańsk.

Skwarczyńska Stefania (1931), O pojęcie literatury stosowanej, "Pamiętnik Literacki”, issue 1.

Skwarczyńska Stefania (1937/2006), Teoria listu, ed. Felisiak E., Leś M., Wydawnictwo Uniwersytetu w Białymstoku, Białystok.

Skwarczyńska Stefania (1975), Wokót teorii listu (Paradoksy) [in:] Skwarczyńska S., Pomiędzy historiq a teoria literatury, Instytut Wydawniczy Pax, Warszawa.

Szymborska Wisława, Filipowicz Kornel (2016), Listy. Najlepiej w życiu ma twój kot, Wydawnictwo Znak, Kraków.

Trzynadlowski Jan (1975), List i pamiętnik, Dwie formy wypowiedzi osobistej, "Pamiętnikarstwo Polskie", no. 1-4.

Wspólnota [Community], dictionary entry [in:] Stownik jezzyka polskiego, ed. Doroszewski W., sjp.pwn.pl/doroszewski/wspolnota;5518188.html [access: 18.12.2021].

Ziołowicz Agnieszka (2014), Epistolarne kreowanie wspólnoty. O listownych rozmowach Cypriana Norwida, "Studia Norwidiana”, no. 32. 
* Uniwersytet Łódzki, Wydział Filologiczny, Zakład Literatury Polskiej XX i XXI w. ul. Pomorska 1717/174,90-236 Łódź

e-mail:magdalena.wasag@uni.lodz.pl 


\section{Epistolografia jako wyzwanie}

[... piękno listu domaga się, by był on na linii swojego ważkiego celu skuteczny, by swym ciężarem gatunkowym zaważył na stosunkach życiowych, z których wyrósł, dla których był przeznaczony, z którymi jest spleciony, by dało się wyczuć, że faktycznie nie jest on czymś literacko oderwanym, lecz fragmentem życia.

(Skwarczyńska 2006: 333-334)

12 listopada 1968 roku Wisława Szymborska pisała z Zakopanego do Kornela Filipowicza:

Kochany Kornelu!

Dziś jest wtorek czyli dzień, w którym masz ciężkie przeżycia. Ale cóż, nie znając szpitala, nie możesz być w pełni człowiekiem współczesnym. Nie jest to moja teoria, tylko kol. Maciąga, który twierdzi, że człowiek XX wieku powinien mieć za sobą trzy doświadczenia 1) więzienie, 2) rozwód, 3) szpital, i dopiero wówczas zdobywa tzw. pełnię świadomości [...]. (Szymborska, Filipowicz 2016: 148)

W listach przyszłej noblistki i mistrza opowiadania harmonijnie przejawiają się elementy literackie i życiowe. Odznaczają się one ironią i humorem, które stają się swoistym kodem komunikacji. Jeżeli szukalibyśmy momentu węzłowego, który zaważył na wzmożonej dynamice korespondencji Szymborskiej i Filipowicza, moglibyśmy śmiało wskazać niemal półroczną kurację poetki w zakopiańskim sanatorium. Doświadczanie choroby, przymusowa izolacja i wiążące się z nią osamotnienie rozbroiła jednak inwencja twórcza korespondentów, ich wyobraźnia i absurdalny żart. Gdybyśmy spróbowali podążyć niezmiennie aktualnym tropem zaproponowanym przez Stefanię Skwarczyńską i zastanowili się, na czym polega piękno tych listów, ponowimy pytanie o ich istotę. Dotkniemy kwestii decydujących, takich jak niebanalna osobowość korespondentów, którzy mimo niewesołej rzeczywistości PRL, codziennych problemów z aprowizacją, zmagań z biurokracją i cenzurą, piszą do siebie żarliwie i tworzą własny intymny świat. Przenikanie się życia i fikcji, gra miłosna, nakładanie masek hrabiny Heloizy Lanckorońskiej i Eustachego Pobóg-Tulczyńskiego to szczególne stemple tych listów. 
Warto dodać, że właśnie w korespondencji niczym w wyjątkowym laboratorium czytelnicy odkrywają wrażliwość Szymborskiej i Filipowicza na wszelkie formy istnienia, rośliny, zwierzęta. „Najlepiej w życiu ma twój kot” to fraza, która dobrze obrazuje relację korespondentów obdarzonych empatyczną wyobraźnią. Listy, których bohaterami jest natura, koty, psy, ptaki, otwierają intrygujące perspektywy interpretacyjne. Pozwalają wniknąć w warsztat twórczy pisarzy. W przypadku Filipowicza, którego opowiadania niuansują m.in. związki ludzkie-zwierzęce, obserwacje czynione przez niego na biwakach i streszczane Szymborskiej nabierają ważnego znaczenia zarówno pod względem genetyki jego tekstów, jak i wątków biograficznych. 4 lipca 1971 roku Filipowicz pisał: „jesteśmy już na biwaku pod 3 dębami, $15 \mathrm{~km}$ od Śremu, 12 godzin cienia, $30 \mathrm{~m}$ do [nieczyt.], $50 \mathrm{~m}$ do zalewu. Komarów - nie ma. Krajobraz jest tak piękny, można powiedzieć - zbyt piękny, jakby za chwilę miał być zniszczony" (Szymborska, Filipowicz 2016: 245). Żartobliwy ton informacji o biwaku został przełamany zaskakująco niepokojącym zdaniem. Wydaje się, że Filipowicz daje się tutaj poznać jako człowiek XX wieku, którego nie zwodzi beztroski urok pięknego krajobrazu. Jako więzień obozów koncentracyjnych przekonał się, jak działa machina zniszczenia. Można przypuszczać, że wstrząsające wojenne doświadczenia skonfrontowane z doskonałością krajobrazu, którego ślad odnajdujemy w liście do Szymborskiej, posłużyły mu jako inspiracja do napisania opublikowanego w 1972 roku w tomie Śmierć mojego antagonisty opowiadania Krajobraz doskonaty ${ }^{1}$. Przeczucie zagrożenia nawet w skrajnie doskonałym otoczeniu Filipowicz opisał z przenikliwością. To tym cenniejsza i bardziej przejmująca obserwacja, kiedy umieścimy ją w kontekstach: biograficznym, historycznym i politycznym. Można dostrzec w niej ogólniejszy rys charakterystyczny dla kondycji współczesnego człowieka, który doświadczył wojennego wyniszczenia i przekonał się o ulotności wszelkiego piękna.

W XXI wieku, kiedy epistolografia związana z tradycyjną papierową formą zapisu zanika (zob. Adamczewska 2012: 531-533), korespondencja Szymborskiej i Filipowicza staje się bezcennym świadectwem dawnych praktyk, przemyślanego doboru papieru listowego, dodatków w postaci listków, dopisków, kolaży, pocztówek i rysunków. Pozostaje także dowodem sensualnego wymiaru korespondencji — zjawiska z pogranicza życia i sztuki.

\section{Na pograniczach}

Ukazujące się wciąż nowe tomy korespondencji dowodzą zainteresowania czytelniczek i czytelników listami, ich autorem, formą, stylem, tłem historycznym etc. Zaproponowany w nich układ według adresatów bądź układ tematyczny wpływa na odbiór czytelniczy, oświetla autora w sieci różnych relacji, uwypukla konkretne zagadnienia. Zbiory opublikowanych listów z XX wieku zostały zdominowane przez korespondencję pisarzy (zob. Czermińska 1993). Przykłady znakomitych epistolografów można mnożyć, wystarczy wspomnieć Brunona Schulza, Stanisława Witkiewicza, Stanisława Ignacego Witkiewicza, Jarosława Iwaszkiewicza, Juliana Tuwima, Jerzego Giedroycia, Jerzego Stempowskiego, Czesława Miłosza, Sławomira Mrożka, Stanisława Lema. Należy jednak podkreślić, że listy są przedmiotem badań nie tylko literaturoznawców, ale także językoznawców, historyków, socjologów, antropologów, kulturoznawców.

1 „Dodam jeszcze tylko, że w pięknie tego miejsca było coś nad wyraz niepokojącego. Coś, co sprawiło, że po kilku dniach pobytu tutaj poczuliśmy się jacyś niepewni swojego losu, jakby czymś zagrożeni. Skąd się to brało? Może właśnie z tej skończonej doskonałości otaczającego nas krajobrazu? [...] A może krajobraz nie był niczemu winien, może źródło niepokoju było w nas samych?” (Filipowicz 2021: 162). 
Współcześnie wciąż niewątpliwie jednym z ważniejszych postulatów dotyczących badań epistolografii jest potrzeba interdyscyplinarności. Analiza listów z wykorzystaniem różnych metod badawczych wydaje się rozwiązaniem, z którym wiążą się konkretne konsekwencje opisywane przez badaczy zgłębiających m.in. relacje epistolografii i biografii. Do opisu korespondencji często wykorzystywane są narzędzia wypracowane w badaniach autobiografii ${ }^{2}$. Małgorzata Czermińska w monografii poświęconej postawom autobiograficznym wyróżniającym literaturę dokumentu osobistego we wprowadzeniu do relacji listu i utworów literackich rekapitulowała podejście naukowe do epistolografii, która była traktowana jako źródło historyczne, rodzaj dokumentu ${ }^{3}$ i komentarza do twórczości ${ }^{4}$. Formy epistolarne ze względu na swoją specyfikę wymykają się metodom stricte literackim. O konieczności odwołania m.in. do biografii w badaniach literatury stosowanej pisała Skwarczyńska w fundamentalnej Teorii listu:

Ponieważ rzeczywistość otaczająca list przekracza granice zjawisk literackich, a tyczy zdarzeń czysto życiowych, będzie mogła ją uchwycić tylko nauka historyczna, więc i metody właściwe tej nauce. Zwłaszcza podstawową będzie biografistyka, która pozwoli poznać życie autora i jego adresatów. (Skwarczyńska 2006: 334)

Nie dziwi zatem, że właśnie w monografii poświęconej biografii naukowej Anita Całek porusza problem korespondencji. Badaczka, podążając śladem kanonicznych już rozpoznań Jana Trzynadlowskiego (zob. 1975), zwróciła uwagę na dwustronny charakter biografii i korespondencji. Odwołując się do obszarów, w których umiejscawiano epistolografię (autokreacyjnego, komunikacyjnego, antropologicznego), stara się wskazać na użyteczne narzędzia analityczne służące re-konstrukcji życia twórcy (Całek 2013: 197). Przenikanie się perspektywy biograficznej i epistolograficznej istotnie wpływa bowiem na wybór określonych narzędzi badawczych. Truizmem jest konstatacja, jak ważnym materiałem źródłowym dla biografa są listy zarówno wydane i już opracowane krytycznie, jak i te znajdujące się w archiwach, często rozproszone. Wydaje się, że Całek bliska jest m.in. perspektywa egzystencjalna w badaniach epistolograficznych zaproponowana przez Kazimierza Cysewskiego, według którego: „Potrzebne jest widzenie listów jako całościowego obrazu serca i losu, ob ra zu nie tylko intencjonalnego, a więc »włączenie « do semantyki listów rysującego się w nich obrazu autora i adresata” (1997: 109). Zgodnie z rozpoznaniem Cysewskiego autokreacja jest składnikiem obrazu autora ${ }^{5}$. W związku z określonymi zabiegami, które mają za zdanie stworzyć pożądany obraz autora, powstaje pewnego rodzaju konstrukcja. Cysewski, uwzględniając więc perspektywę tekstu, wprowadził termin „podmiotu epistolarnego”, który nie jest tożsamy z osobą realnego autora. W tym ujęciu ważne staje się odkrycie strategii

2 O konsekwencjach autobiografizacji epistolografii pisała Elżbieta Rybicka (2004: 46-48).

3 O liście jako „autonomicznym rodzaju literackim” pisała Stefania Skwarczyńska w monografii z 1937 r., przeciwstawiając się postawie traktowania listu wyłącznie jako formy służebnej, dokumentarnej.

4 Zob. Czermińska 2000: 252. Elżbieta Rybicka wprowadziła natomiast do polskiego literaturoznawstwa typologię listu Brigitte Diaz, która zaproponowała rozumienie listu z uwzględnieniem jego czterech współistniejących postaci jako: dokumentu, tekstu, dyskursu i działania. Zob. Diaz 2002.

5 Według Cysewskiego:

Zdania, które traktujemy jako wyraz zabiegów autokreacyjnych, mogą być zarówno prawdziwe, jak i fałszywe. Wynika z tego, że autokreacja to nie problem prawdy lub fałszu, lecz typ i „kierunek” znaczeń tekstu, to pewien sposób użycia języka, to jedna z funkcji języka w dziele. (Cysewski 1997: 104) 
epistolarnej, która określa m.in. sposób komunikacji z adresatem i jest wyrazem osobowości autora. W kontekście tych rozważań oryginalną koncepcją jest Nowa teoria listu, w której Anita Całek proponuje rozumienie listu jako tekstu kultury:

[...] jako gatunek wypowiedzi stanowi całość odrębną, autonomiczną, specyficznie skomponowaną i wyznaczającą własne wewnętrzne reguły komunikacyjne, równolegle wchodzi w interakcje z rzeczywistością (do której się odnosi), nadawcą (oraz wydawcą i badaczem - jako nadawcami "drugiego", a także „trzeciego" poziomu) i odbi o r cą (oraz czytelnikami - odbiorcami na kolejnych poziomach opublikowanej lub upublicznionej korespondencji). (Całek 2019: 82)

Warto przywołać również interesujący postulat Lucyny Marzec, która odwołując się do teorii medium Williama J.T. Mitchella, pisała m.in.: „List przypomina medium pod wieloma względami — to » ucieleśniony posłaniec, nie sam przekaz «, jest materialnym środkiem komunikowania się [...]" (Marzec 2015: 94). W dociekaniach badaczy powraca paradoks komunikacyjny listu, który jest jednocześnie dialogiem i monologiem (Skwarczyńska 1975). Prócz tego pojawia się także wymiar psychologiczny korespondencji, kiedy epistolograf stara się wniknąć w psychikę adresata. Do opisu relacji listowych istotne okazują się więc również kategorie psychologiczne i filozoficzne. Ale przecież nie tylko. Interesującym zagadnieniem jest wymiana listów będąca rodzajem dialogu dramatycznego. Magdalena Popiel ujmuje w tym kontekście listy Stanisława Wyspiańskiego, wskazując list artysty jako gatunek narracji epistolograficznej ${ }^{6}$. Zdaniem badaczki dialog i pisanie listów dramatopisarza rządziły się określonymi zasadami. Jednym z ich warunków była ciągłość. Dialog i korespondencja mają bowiem swój rytm, decydujący o ich istocie. Brak odpowiedzi na czas psuje dzieło. Dla Wyspiańskiego pisanie listów to współtworzenie „świadomej wspólnoty celów, reguł i wartości” (Popiel 2004: 119). Zdaje się, że wspomniana w s p ó l n o t a uzmysławia znaczenie epistolografii w praktykach twórczych artystów, dla których listy były szczególnym medium międzyludzkich więzi - miały moc wspólnototwórczą (zob. Ziołowicz 2014). Ws p ól n o t a, czyli m.in. „to, co łączy, zespala; więź, spójnia” (Wspólnota). To w domyśle także wspólnota duchowa, której świadectwem poszukiwania jest m.in. korespondencja Brunona Schulza (2008). Innymi słowy, to listy pomagają zacieśniać ważne więzi, to listy istotnie wprowadzają artystę do rodziny twórczych duchów, stają się przejawem trwałej i głębokiej przyjaźni. W tym kontekście można przywołać znakomitą korespondencję Juliana Tuwima do przyjaciół-pisarzy. To oczywiście nieprzypadkowy wybór tytułu ${ }^{7}$. Znamienne, że swoistym kluczem „przyjaciół-

6 „Do kogo pisze artysta? Oczywiście do artysty. [...] Dyskurs listu będzie koncentrował się na potwierdzeniu tożsamości artysty. W komunikacji epistolarnej dialog z konkretnym odbiorcą, a więc sytuacja zasadniczo różna od dziennika, pamiętnika czy autobiografii, jest swoistą prowokacją dla tożsa mości kreacyjnej artysty. W tę konfigurację ja-ty wkraczają dwa elementy o mocy artefaktycznej: dystans i medium. Oddalenie i zapełniona znakami kartka papieru tworzą scenariusz spektaklu. Tworzą także rolę, w którą wchodzi nadawca: rolę artysty w działaniu, artysty w akcji” (Popiel 2004: 116).

7 Tadeusz Januszewski wyjaśniał we wstępie do listów Tuwima:

Wydawca pragnie szczególnie podkreślić, że nie czuje się kompetentny do wydawania opinii w sprawie tak delikatnej jak przyjaźń i intencją jego nie było dzielenie adresatów na „przyjaciół” i „innych”. Jeśli mimo to książka nosi tytuł Listy do przyjaciót-pisarzy, a nie Listy do pisarzy, to dlatego, aby wyraźniejszy stał się kierunek penetracji. W tomie starano się zwłaszcza uwzględnić, na ile to było dziś osiągalne, listy do jego dawanych i znanych przyjaciół. [...] Tom niniejszy ukazuje przede wszystkim stosunki łączące Tuwima z innymi pisarzami. Dlatego listy pozostawiono w osobnych zespołach, co pozwoli lepiej prześledzić rozwój przyjacielskich kontaktów. Dlatego również każdy zespół poprzedzony został notą wstępną prezentującą w ogromnym skrócie „dzieje przy- 
-pisarzy” albo ogólniej „przyjaciól-artystów” kierowali się również inni wydawcy, przygotowując do publikacji tomy korespondencji ${ }^{8}$. (Interesującym kontekstem korespondencji pisarzy-przyjaciół są także listy, w których autorzy informowali o zerwaniu przyjaźni, tzw. listy rozwodowe wysyłał Lem).

We Wstępie do listów Tuwima Tadeusz Januszewski tłumaczył m.in. trudności i zawiłości dotyczące ich edycji, wskazywał na luki, których wypełnienie pozostaje w sferze przypuszczeń. Niekiedy kłopoty miało sprawiać na przykład ustalenie miejsca napisania listu. Kilkakrotnie okazywało się, że brak przesłanek w tekście i skromny zapas informacji uniemożliwiał jego dokładne ustalenie. Lektura listów bardzo często przypomina praktykę rozszyfrowywania znaczeń. W prywatnej korespondencji, która nie była przeznaczona dla osób trzecich, nadawca listu (epistolograf) zwraca się wyraźnie jedynie do adresata listu. Ponadto zapisane w nim odniesienia i aluzje dla niewtajemniczonego odbiorcy (czytelnika niebędącego adresatem $)^{9}$ są zupełnie enigmatyczne. Dla tej sytuacji komunikacyjnej adekwatne jest spostrzeżenie Czermińskiej dotyczące rozdzielenia ról adresata i czytelnika korespondencji ${ }^{10}$.

Zasygnalizowane $\mathrm{w}$ artykule w ogromnym skrócie teorie i propozycje metodologiczne oczywiście nie wyczerpują wielości perspektyw występujących w badaniach dotyczących epistolografii. Zaledwie zapowiadają różnorodne możliwości i ujęcia. W 2018 roku na łamach "Zagadnień Rodzajów Literackich” został opublikowany artykuł Jakuba Osińskiego ${ }^{11}$, który przeprowadzał rekonesans dotyczący emigracyjnej epistolografii (1945-1989) i postulował konieczność badań nad emigracyjną korespondencją, mającą inny charakter niż krajowa. Apel ten warto powtórzyć także obecnie, w momencie ukazywania się zeszytu poświęconego tematowi epistolografii i wyzwań, które stoją przed badaczami zarówno opublikowanej korespondencji, jak i listów spoczywających w archiwach w Polsce i za granicą. Mam nadzieję, że teksty zebrane w tym zeszycie są dowodem potrzeby rozwijania i pogłębiania badań dotyczących epistolografii; uwzględniają bowiem bardzo różne perspektywy teoretyczne i pomysły interpretacyjne. Są także świadectwem pewnej szczególnej kontynuacji, twórczych odniesień do Teorii listu Stefanii Skwarczyńskiej.

Serdecznie zapraszam do lektury specjalnego numeru poświęconego epistolografii.

jaźni”, a zwłaszcza informacje i materiały, które nie znalazły się w przypisach. Ten układ — wzorowany zresztą na znakomitym wydaniu listów Staffa — wynika z zawartości książki i nie może być powtarzany we wszystkich tomach. (Januszewski 1979: 5-6)

8 Zob. m.in. Julia Hartwig, W kręu przyjaźni (2012).

9 Ważne rozgraniczenie terminów „adresat” i „odbiorca” w przypadku epistolografii podkreślał także K. Cysewski:

Przyjmuję, że adresat to osoba, do której list został napisany, to konkretny, semantycznie wyznaczony jego czytelnik; odbiorca natomiast to „podglądacz” cudzej korespondencji, czytelnik nie będący adresatem. (Cysewski 1997: 106)

Całkowity rozdział pomiędzy adresatem a czytelnikiem istnieje tylko w wypadku korespondencji wyraźnie nie przeznaczonej dla osób trzecich. Wówczas „Ty” zwrócone jest wyłącznie do adresata, czytelnik nie znajduje tam miejsca przewidzianego dla siebie, chwilami prowadzi to do zupełnego niezrozumienia tekstu: dopiero przypis wydawcy otwiera przed niewtajemniczonym czytelnikiem jakąś aluzję czy swego rodzaju „szyfr prywatny” w postaci skrótów, przezwisk itp. (Czermińska 2000: 263) 


\section{Bibliografia}

Adamczewska Izabella (2012), List [w:] Stownik rodzajów i gatunków literackich. Nowe wydanie, red. Gazda G., Wydawnictwo Naukowe PWN, Warszawa.

Całek Anita (2013), Biografia naukowa: od koncepcji do narracji. Interdyscyplinarność, teorie, metody badawcze, Wydawnictwo Uniwersytetu Jagiellońskiego, Kraków.

Całek Anita (2019), Nowa teoria listu, Księgarnia Akademicka, Kraków.

Cysewski Kazimierz (1997), Teoretyczne $i$ metodologiczne problemy badań nad epistolografia, „Pamiętnik Literacki”, t. 88, z. 1.

Czermińska Małgorzata (1993), Epistolarne formy [w:] Stownik literatury polskiej XX wieku, red. Brodzka A. i in., Zakład Narodowy im. Ossolińskich, Wrocław.

Czermińska Małgorzata (2000), Autobiograficzny trójkąt. Świadectwo, wyznanie i wyzwanie, Universitas, Kraków.

Diaz Brigitte (2002), Lèpistolaire ou la pensée nomade. Formes et fonctions de la correspondance dans quelques parcours d'écrivains au XIX siècle, Presses Universitaires de France, Paris.

Filipowicz Kornel (2021), Krajobraz doskonaty [w:] Filipowicz K., Formikarium, czyli w moim świecie mrówek. Opowiadania, wybór i wstęp Dauksza A., Wydawnictwo Znak, Kraków.

Hartwig Julia (2012), W kręgu przyjaźni [w:] Korespondencja. Artur Międzyrzecki i Julia Hartwig, Czestaw Mitosz, Wydawnictwo Literackie, Kraków.

Januszewski Tadeusz (1979), Wstęp [w:] Tuwim J., Listy do przyjaciót-pisarzy, oprac. Januszewski T., Czytelnik, Warszawa.

Marzec Lucyna (2015), List, „Forum Poetyki”, nr 1 (lato), http://fp.amu.edu.pl/wp-content/ uploads/2015/07/Lucyna_Marzec_List_lato_2015.pdf [dostęp: 20.12.2021].

Osiński Jakub (2018), Emigracyjna epistolografia (1945-1989). Rekonesans, „Zagadnienia Rodzajów Literackich", t. 61, z. 3.

Popiel Magdalena (2004), List artysty jako gatunek narracji epistolograficznej. O listach Stanistawa Wyspiańskiego, „Teksty Drugie”, nr 4.

Rybicka Elżbieta (2004), Antropologiczne i komunikacyjne aspekty dyskursu epistolograficznego, „Teksty Drugie”, nr 4.

Schulz Bruno (2008), Księga listów, zebrał i przygotował do druku Ficowski J., wyd. 3, słowo/ obraz terytoria, Gdańsk.

Skwarczyńska Stefania (1931), O pojęcie literatury stosowanej, „Pamiętnik Literacki”, t. 28, z. 1.

Skwarczyńska Stefania (1937/2006), Teoria listu, oprac. Felisiak E., Leś M., Wydawnictwo Uniwersytetu w Białymstoku, Białystok.

Skwarczyńska Stefania (1975), Wokót teorii listu (Paradoksy) [w:] Skwarczyńska S., Pomiędzy historia a teoria literatury, Instytut Wydawniczy Pax, Warszawa.

Szymborska Wisława, Filipowicz Kornel (2016), Listy. Najlepiej w życiu ma twój kot, Wydawnictwo Znak, Kraków.

Trzynadlowski Jan (1975), List i pamiętnik, Dwie formy wypowiedzi osobistej, „Pamiętnikarstwo Polskie", nr 1-4.

Wspólnota [w:] Stownik jezzyka polskiego, red. Doroszewski W., sjp.pwn.pl/doroszewski/wspolnota;5518188.html [dostęp 18.12.2021].

Ziołowicz Agnieszka (2014), Epistolarne kreowanie wspólnoty. O listownych rozmowach Cypriana Norwida, „Studia Norwidiana”, nr 32. 